\title{
Acute kidney injury after cardiac surgical operations specially including coronary artery bypass graft operations
}

\author{
Adam Lipski', Marta Szymoniak-Lipska', Krzysztof Greberski \\ ${ }^{1}$ Students' Scientific Association of Cardiac Surgery, Department of Cardiac Surgery, Hospital J.Strusia, Poznan, Poland \\ ${ }^{2}$ Department of Cardiovascular Prevention, The University of Medical Sciences Poznań, Department of Cardiac surgery \\ Hospital J.Strusia, Poznan, Poland
}

\begin{abstract}
Introduction. Acute kidney injury as abrupt loss of kidney function leads to accumulation nitric and non-nitric metabolites, toxins. It coexists with deep disorder of fluid balance. Most of cardiac surgical operations are performed using extracorporeal circulation (ECC). To the main risk factors of the postoperative dysfunction of kidneys belong: age above 70, congestive heart failure, previous $C A B G$, preoperative creatinine concentration 124-177 $\mu \mathrm{mol} / \mathrm{L}$, diabetes type I, glucose concentration $>16,6 \mathrm{mmol} / \mathrm{L}$, EEC longer than 3 hours and decreased cardiac output (CO).

Material and methods. The serum creatinine is not enough sensitive marker to diagnose early period of acute kidney injury because the serum creatinine increase occur later than true GFR changes and it needs time to accumulate. It depends on factors like: age, sex, weight, hydration status and what patient eat. NGAL (neutrophil-gelatinase associated lipocalin), cystatin C, KIM-1, IL-18, L-FABP are new markers of acute kidney injury which better than the serum creatinine concentration correspond with kidney injury. The risk factors of the acute kidney injury (AKI) are kidney hypoperfusion, microembolisation by bubbles or material particles and significant activation of humoral factors.

Results. One of the methods reducing mortality CSA-AKI (cardiac surgery associated kidney injury) is renal replacement therapy (RRT), which should be used in early period of acute kidney disease before severe symptoms and complications develop.

Conclusions. There is necessity to find early, easy and cheap markers of acute kidney injury which help decide if use renal replacement therapy. It increases the effectiveness of treatment and improves prognosis in this group of patients.
\end{abstract}

Keywords: Acute kidney injury (AKI), Cardiac surgery associated kidney injury (CSA-AKI), Renal replacement therapy (RRT).

\section{Definition of acute kidney injury}

Acute kidney injury as abrupt loss of kidney function leads to accumulation nitric and non-nitric metabolites, toxins. It coexists with deep disorder of fluid balance. Acute kidney injury (AKI) is defined (according to KIDGO 2012) ${ }^{[1]}$ as increasing of creatinine concentration in serum $0,3 \mathrm{mg} / \mathrm{dl}(26,5 \mu \mathrm{mol} / \mathrm{l})$ within 48 hours, or
1,5 times more of creatinine within 7 days, or diuresis $<0,5 \mathrm{ml} / \mathrm{kg} / \mathrm{h}$ within $6 \mathrm{~h}$. According to international RIFLE criteria (Risk, Injury, Failure, Loss and End-stage renal disease) (Table 1) we can evaluate risk, injury and development of kidney disease (loss of function and end-stage renal disease). 
Table 1. Criteria RIFLE

\begin{tabular}{|c|c|c|}
\hline Class & GFR Criteria & Urine Output Criteria \\
\hline Risk & $\begin{array}{c}\text { Increased Serum Creatinine x } 1.5 \\
\text { or } \\
\text { GFR decrease }>25 \%\end{array}$ & $<0.5 \mathrm{ml} / \mathrm{kgmc} / \mathrm{h}$ within $6 \mathrm{~h}$ \\
\hline Injury & $\begin{array}{c}\text { Increased Serum Creatinine x } 2 \\
\text { or } \\
\text { GFR decrease }>50 \%\end{array}$ & $<0.5 \mathrm{ml} / \mathrm{kgmc} / \mathrm{h}$ within $12 \mathrm{~h}$ \\
\hline Failure & $\begin{array}{c}\text { Increased Serum Creatinine x } 3 \\
\text { or } \\
\text { GFR decrease }>75 \% \\
\text { or } \\
\text { Serum Creatinine } \geqslant 4 \mathrm{mg} / \mathrm{dl} \text { with acute rise } \geqslant 0.5 \mathrm{mg} / \mathrm{dl}\end{array}$ & $\begin{array}{c}<0.3 \mathrm{ml} / \mathrm{kgmc} / \mathrm{h} \text { within } 24 \mathrm{~h} \\
\text { or } \\
\text { anuria within } 12 \mathrm{~h}\end{array}$ \\
\hline Loss of function & \multicolumn{2}{|c|}{ Persistent acute renal failure $=$ complete loss of kidney function $>4$ weeks } \\
\hline End-stage renal disease (ESRD) & \multicolumn{2}{|c|}{ End stage kidney disease (> 3 months) } \\
\hline
\end{tabular}

\section{Risk factors of acute kidney insuffi- ciency}

Among the most often performed cardiac surgical operations we can mention Coronary Artery Bypass Graft (CABG) with or without off-pump coronary artery bypass (OPCAB), surgery of the mitral, aortic and tricuspid valve, surgery of aneurysm of the ascending aorta, aneurysm of the arch, surgery of aorta dissection. Apart from OPCAB most of these procedures are performed using extracorporeal circulation (ECC). To the main risk factors of the postoperative dysfunction of kidneys belong: age above 70, congestive heart failure, previous CABG, preoperative creatinine concentration 124-177 $\mu \mathrm{mol} / \mathrm{L}$, diabetes type I, glucose concentration > 16,6 mmol/L, EEC longer than 3 hours and decreased cardiac output (CO) (Table 2).

\section{Etiology of acute kidney injury after cardiac surgical operations}

Prevalence of acute kidney injury after cardiac surgical operations are between 7,7\% [2] and 42\% [3]. One of the main acute kidney injury (AKI) risk factors is kidney hypoperfusion connected with low blood volume and

Table 2. Risk factors of postoperative AKI for patients who were underwent CABG

\begin{tabular}{ll}
\hline \multicolumn{1}{c}{ Rlsk factors } & Relative risk (95\% Cl-Cardiac index) \\
\hline preoperative & \\
\hline age & $1.6(1.1-2.3)$ \\
\hline $70-79$ & $3.5(1.9-6.3)$ \\
\hline $80-95$ & $1.8(1.3-2.6)$ \\
\hline congestive heart failure & $1.8(1.2-2.7)$ \\
\hline Previous CABG & $2.3(1.6-3.4)$ \\
\hline Preoperative creatine concentratiom 124-177 $\mu \mathrm{mol} / \mathrm{L}$ & \\
\hline Diabetes & $1.8(1.1-3.0)$ \\
\hline Diabetes type I & $3.7(1.7-7.8)$ \\
\hline Glucose concentration $>16.6 \mathrm{mmol} / \mathrm{L}$ & \\
\hline Midoperetive and postoperetive & $2.8(1.9-7.2)$ \\
\hline ECC longer than 3 hours & \\
\hline Decreased cardiac output* & $4.5(2.9-7.2)$ \\
\hline significantly & $3.1(1.9-4.9)$ \\
\hline moderately & $4.3(2.2-8.5)$ \\
\hline mildly &
\end{tabular}

*Significantly: Intra-aortic balloon pump (IABP); moderately: 1) cardiac index $<1.5 \mathrm{~L} / \mathrm{min} / \mathrm{m}^{2}$ surface of the body during at least 30 minutes or at least three inotropes, 2) congestive heart failure confirmed by $\mathrm{Cl}<1.5 \mathrm{~L} /$ $\mathrm{min} / \mathrm{m}^{2}$, 3) PCWP - pulmonary capillary wedge pressure $>18 \mathrm{mmHg}$, or 4) central venous pressure $>12$ $\mathrm{mmHg}$; mildly: congestive heart failure confirmed by rales, murmurs, chest radiograph, or widening of the jugular veins. 
disorder of blood pressure. If there were not appropriate procedure the condition of GFR functional decreasing lead to actin cytoskeleton disintegration, loss intercellular tight junctions, disorder of integrins functions and in result epithelium of convoluted tubule desquamation [4-6]. Another reason of acute kidney injury after cardiac surgical operations is microembolisation which is caused bubbles or material particles [7]. During cardiac surgical operation blood is undergone shear strain when it has contact with artificial material in extracorporeal circulation. It leads to red blood cells damage and hemoglobin and iron release that have redox activity. Redox reactions induce lipid peroxidation and tissue damage [8]. After cardio surgical operation with using cardiopulmonary bypass there is significant activation of humoral factors. Artificial surface activates XII coagulation factor and stimulates coagulation cascade and in result also fibrinolysis. Complement system is activated in classical pathway and alternative pathway. In the same time there are platelet activation, degranulation, adhesion to endothelium, neutrophil and endothelium activation. They result in increasing concentration of adhesion molecule, cytokines, chemokines, lytic enzymes and reactive oxygen species [9-16].

\section{Markers of acute kidney injury}

The serum creatinine is not enough sensitive marker to diagnose early period of acute kidney injury because the serum creatinine increase occur later than true GFR changes and it needs time to accumulate. The serum creatinine concentration depends on factors which is not directly connected with kidney like: age, sex, weight, hydration status and what patient eat.

NGAL (neutrophil-gelatinase associated lipocalin) is protein secreted into urine by thick ascending limb of loop of Henle and collecting duct cells. NGAL takes part in iron complex chelation and recirculation of iron complex by endocytosis that protects renal tubule from ischemic [17]. Excretion NGAL with urine significantly increases in AKI caused ischemia [18], especially after cardiac surgical operations [19] or kidney transplant $[20,21]$, after application big dose contrast agents [22] or other nephrotoxic substance [23, 24]. There was not observed significant increase of NGAL excretion after coronary catheterization [25].

Cystatin $C$ in serum is earlier than creatinin marker of kidneys' function used as well to identify progressive changes as to detect dysfunction. Cystatin C is non-glycosylated protein, endogenic inhibitor of cysteine proteases, produced and released into blood in constant rate by all nucleated cells. The concentration of cystatin $C$ in serum is independent of age, sex, race, body weight and hydration status and can be measured using easy nephelometric method. Relatively high concentration in body fluid, low mass (13,3 kDa) and positive electric charge of this protein ensure easy glomerular filtration to primary urine. In proximal coils it's completely reabsorbed and catabolized. Because of constant rate of production the value of concentration cystatin $C$ can be a marker of glomerular filtration what is more it does not depend on any factors as: infection, liver diseases, inflammatory diseases [26, 27]. Using cystatin C dysfunction of kidney's can be detected in critical state patients with AKI (24-48 hours earlier than using creatinin). However it is not a specific marker for AKI, because it is rather an early marker of glomerular filtration than a marker of dysunction of coils [28-30].

KIM-1 (kidney injury molecule 1) - it is a transmembrane orphan receptor produced produced in a large amount in proximal coil because of toxic or ischemic injury. The extracellular domain is removed in urine. vi the increase its excretion is combined with surgery of abdominal aorta aneurysm, heart (precedes the increase of creatinine), but it was not detected in contrast nephropathy [31, 32].

IL-18 is proinflammatory cytokin released into urine by epithelium of proximal ducts after some kind nephrotoxic factor occurred. Concentration above 100 pg/ mg creatinin corresponds well with risk of AKI and death in patients with acute respiratory disorders syndrome [33] and it predicts that the kidney will work with deley after trasplantation [34]. Increase in concentration of II-18 can be detected in first hours after cardiovascular surgery in children [35]. Examination of IL-18 in urine allows to discern very early stage of kidney injury caused by ischemia or coil nephrotoxin and let us excluded prerenal azotemia, chronic kidney disease and urinary tract infection [36]. Furthermore IL-18 is a predictor of AKI severity and probability of death.

L-FABP is cytoplasmic protein responsible for intracellular transport of long-chain fatty acid. There are known 9 types of proteins transporting fatty acid and L-FABP is one of them. They are relatively specific to the tissue. L-FABP can be found in hepatocytes, enterocytes, and the proximal coil cells. In different kidneys injuries concentration L-FABP in urine increases. It was proved that L-FABP is a adequate marker of AKI after cardiac surgery. Its concentration increased in urine 94 times and 45 times more than in people who were not 
underwent such procedures properly in 4. and 12. hour after surgery. The concentration of L-FABP increases faster than of creatinin [37]. It was revealed that the concentration of L-FABP is useful in in the monitoring of contrast-induced nephropathy [38], cis-platin induced nephropathy [39], and also in the staging of chronic kidney disease [40].

\section{Methods of reduction mortality con- nected with acute kidney injury (AKI)}

Prevalence of acute kidney injury connected with cardiac surgical operations (cardiac surgery associated kidney injury - CSA-AKI) in early after-operation period may be even $30 \%$ and it increases because more people are operated in old age and with co-exited disease e.g. diabetes or chronic kidney disease [41] One of the methods reducing mortality CSA-AKI is renal replacement therapy (RRT), which should be used in early period of acute kidney disease before severe symptoms and complications develop. Increase serum creatinine concentration and GFR decrease occur in $2^{\text {nd }}-3^{\text {rd }}$ day after damaging agent. It provides big loss of nephrons which often is irreversible. In many department of cardiac surgery the serum creatinine serum concentration is still main way to evaluate kidney function. There is necessity to find early, easy and cheap markers of acute kidney injury which help decide if use renal replacement therapy. It increases the effectiveness of treatment and improves prognosis in this group of patients.

\section{Acknowledgements}

\section{Conflict of interest statement}

The authors declare that there is no conflict of interest in the authorship or publication of contribution.

\section{Funding sources}

There are no sources of funding to declare.

\section{References}

1. Bellomo R, Ronco C, Kellum JA, Mehta RL, Palevsky P and the $A D Q$ I workgroup: Acute renal failure - definition, outcome measures, animal models, fluid therapy and information technology needs: the Second International Consensus Conference of the Acute Dialysis Quality Initiative (ADQI) Group. Critical Care. 2004;8:R204 - R212.

2. Mangano CM, Diamondstone LS, Ramsay JG et al. Renal dysfunction after myocardial revascularization: Risck factors, adverse outcomes, and hospital resourse utilization. Ann Intern Med. 1998;128:194.
3. Tuttle KR, Worrall NK, Dahlstrom LR et al. Predictors of ARF after cardiac surgical procedures. Am J Kidney Dis. 2003;41:76.

4. Kokot M, Duława J. AKI - ostre uszkodzenie nerek współczesne spojrzenie na zagadnienie ostrej niezapalnej niewydolności nerek. Nefrol Dial Pol. 2009;13:164-170.

5. Palevsky MP, Murrat PT. Acute Kidney Injury and Critical Care Nephrology. NephSAP. 2006;5:72.

6. Sutton TA, Fisher CJ, Molitoris BA. Microvascular endothelial injury and dysfunction during ischemic acute renal failure. Kidney Int. 2002;62:539.

7. Sreeram GM, Grocott HP, White WD et al. Trancranial Doppler emboli count predicts rise in creatinine after coronary artery bypass graft surgery. J Cardiovasc Vasc Anesth. 2004;18:548.

8. Gutteridge JMC. Iron promoters of the Fenton reaction and lipid peroxydation can be releeased from hemoglobin by peroxidie. Fed Eur Biochem Soc Lett. 1986;201:291.

9. Bonventre JV, Zuk A. Ischemic acute renal failure: An inflammatory disease? Kidney Int. 2004;66:480.

10. Burne-Taney MJ, Rabb H. The role of adhesion molecules and T cells in ischemic renal injury. Curr Opin Nephrol Hypertens. 2003;12:85.

11. Frering B, Philip I, Dehous M et al. Circulating cytokines in patients undergoing normothermic cardiopulmonary bypass. J Thorac Cardiovasc Surg. 2002;21:232.

12. Kinsey GR, Li L, Okusa MD. Inflammation in acute kidney injury. Nephron Exp Nephrol. 2008;109:e102.

13. Kirklin JK, Westaby S, Blackstone EH et al. Complement and the damaging effects of cardiopulmonary bypass. J Thorac Cardiovasc Surg. 1983;86:845.

14. Musial J, Niewiarowski S, Hershock D et al. Loss of fibrinogen receptors from the platelet surface duringsimulated extracorporeal circulation. J Lab Clin Med. 1985:105:514.

15. Paparella D, Yau TM, Young E. Cardiopulmonary bypass induced inflammation: Patophysiology and treatment. An update. Eur J Cardiothorac Surg. 2002;21:232.

16. Sheridan AM, Bonventre JV. Cell biology and molecular mechanisms of injury in ischemic acute renal failure. Curr Opin Nephrol Hypertens. 2000;9:427.

17. Mori $\mathrm{K}$ et al. Endocytic delivery of lipocalin siderophore-iron complex rescues the kidney from ischemia-reperfusion injury. J Clin Invest. 2005;115:610-621.

18. Mishra J et al. Amelioration of ischemic acute renal injury by NGAL. J Am Soc Nephrol. 2004;15:3073-3082.

19. Wagener $\mathrm{G}$ et al. Association between increases in urinary neutrophil gelatinase associated lipocalin and acute renal dysfunction after adult cardiac surgery. Anesthesiology. 2006;105:485-491.

20. Mishra J et al. Kidney NGAL is a novel marker of acute injury following transplantation. Pediatr Nephrol. 2006;21:856-863.

21. Parikh CR et al. Urine NGAL and $\|-18$ are predictive biomarkers for delayed graft function following kidney transplantation. Am J Transplant. 2006;6:1639-1645.

22. Hirsch $R$ et al. NGAL is an early predictive biomarker of contrast induced nephropathy in children. Pediatr Nephrol. 2007;22:2089-2095.

23. Nickolas TL et al. Sensitivity and specificity of a single emergency department measurement of urinary neutrofil 
gelatinase associated lipocalin for diagnosing acute kidney injury. Am Intern Med. 2008;148:810-819.

24. Mishra J et al. Neutrophil gelatinase-associated lipocalin, a novel early urinary biomarker for cisplatin nephrotoxicity. Am J Nephrol. 2004;24:307-315.

25. Bachorzewska-Gajewska $\mathrm{H}$ et al. Neutrophil gelatinase associated lipocalin and renal function after percutaneous coronary interventions. Am J Nephrol. 2006;26:87292.

26. Venkataraman R, Kellum JA. Defining acute renal failure: the RIFLE criteria. J. Intensive Care Med. 2007;22:187193.

27. Royakkers AA, vanSuijlen JD, Hofstra LS. et al. Serum cystatin $C-$ a useful endogenous marker of renal function in intensive care unit patients at risk for or with acute renal failure? Curr Med Chem. 2007;14:2314-2317.

28. Trof RJ, Di Maggio F, Leemreis J, Groeneveld ABJ. Biomarkers of acute renal injury and renal failure. Shock. 2006;26:245-253.

29. Dent $C L$, Ma Q, Dastrala S et al. Plasma neutrophil gelatinase-associated lipocalin predicts acute kidney injury, morbidity and mortality after pediatric cardiac surgery: a prospective uncontrolled cohort study. Crit Care. 2007;11:R127.

30. Lisowska-Myjak B. Labolatroyjne wskaźniki ostrego uszkodzenia nerek oznaczane w moczu i surowicy. Forum Nefrologiczne. 2010;2(3):71-81.

31. Han WK, Wagener G, ZhuY. Urinary biomarkers in the early detection of acute kidney injury after cardiac surgery. Clin J Am Soc Nephrol. 2009;4:873.

32. Zhou H, Hewitt SM, Yuen PS, Star RA. Acute kidney injury biomarkers: Needs, present status, and future promise. NephSAP. 2006;5:63.

33. Parikh CR et al. Urine II-18 is an early diagnostic marker for acute kidney injury and predicts mortality in the intensive care unit. J Am Soc Nephrol. 2005;16:30463052.
34. Parikh CR et al. Urine NGAL and II-18 are predictive biomarkers for delayed graft function following kidney transplantation. Am J Transplant. 2006;6:1639-1645.

35. Parikh CR et al. Urinary II-18 is an early predictive biomarker of acute kidney injury after cardiac surgery. Kidney Int. 2006;70:199-203.

36. Parikh $C R$ et al. Urinary inerleukin-18 is a marker of human acute tubular necrosis. Am J Kidney Dis. 2004:43:405-414.

37. Portilla $D$, Dent $C$, Sugaya $T$. et al. Liver fatty acid-binding protein as a biomarker of acute kidney injury after cardiac surgery. Kidney Int. 2008;73:465.

38. Nakamura T, Sugaya T, Node K. et al. Urinary excretion of liver-type fatty acid-binding protein in contrast medium-induced nephropathy. Am J Kidney Dis. 2006;47:439.

39. Negishi K, Noiri E, Doi K. et al. Monitoring of urinary L-type fatty acid-binding protein predicts histological severity of acute kidney injury. Am J Pathol. 2009;174:1154.

40. Pelsers MM. Fatty acid-binding protein as marker for renal injury. Scand J Clin Lab Invest Suppl. 2008;241:73.

41. Jander S, Ledakowicz-Polak A, Jaszewski R, Zielińska M. Ostre uszkodzenie nerek związane z zabiegami kardiochirurgicznymi - współczesne spojrzenie na problem. Kardiochirurgia i Torakochirurgia Polska. 2011;4:457-461.

Acceptance for editing: $2015-02-4$ Acceptance for publication: 2015-03-30

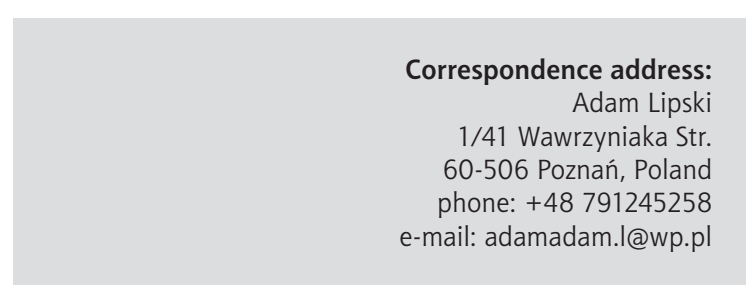

